DOI: $10.14720 /$ aas.2016.107.1.05

Agrovoc descriptors: agrobacterium rhizogenes; genetic engineering; inoculation; root hairs; growing media; rosmarinic acids

Agris category code: F30

\title{
Influences of various factors on hairy root induction in Agastache foeniculum (Pursh) Kuntze
}

\author{
Elnaz NOUROZI ${ }^{1}$, Bahman HOSSEINI ${ }^{2 *}$ and Abbas HASSANI ${ }^{3}$
}

Received April 26, 2015; accepted February 10, 2016.

Delo je prispelo 26. aprila 2015, sprejeto 10. februarja 2013.

\begin{abstract}
Agrobacterium rhizogenes is known as a natural tool of genetic engineering in many plant species. For the first time, hairy root induction in Agastache foeniculum using $A$. rhizogenes, rosmarinic acid content and the effect of different culture media and inoculation methods on hairy root growth rate were investigated. Hairy root culture of $A$. foeniculum was established by inoculation of the 1-month-old leaf explant with A4 strain of $A$. rhizogenes and the effectiveness of light dark conditions and two inoculation methods (immersion and injection) were tested. Furthermore, in immersion method, the effects of inoculation time $(3,5$ and $7 \mathrm{~min})$ on root induction were investigated. In the second part of the study, the hairy root culture of $A$. foeniculum was studied using different basal culture media (MS, 1/2 MS and B5). Rosmarinic acid content in hairy roots and non- transformed roots was analyzed using high-performance liquid chromatography (HPLC). There was no significant difference between various inoculation methods in the ability of hairy roots induction. Observations showed that percentage of hairy root induction was higher when the explants were immersed for $5 \mathrm{~min}$ in bacterial suspension. Light conditions displayed the highest hairy root induction rates compared with dark condition. Various culture media are different in terms of types and amounts of nutrients and have influence on growth rate. The maximum growth rate $(1.61 \mathrm{~g} \mathrm{fr}$ $\mathrm{wt} / 50 \mathrm{ml}$ ) of hairy roots were obtained in $1 / 2 \mathrm{MS}$ medium. Rosmarinic acid content in transformed roots $(213.42 \mu \mathrm{g} / \mathrm{g}$ dry wt) was significantly higher than non-transformed roots $(52.28$ $\mu \mathrm{g} / \mathrm{g}$ dry wt).
\end{abstract}

Key words: Agastache foeniculum, Agrobacterium rhizogenes, culture medium, hairy roots, immersion, injection, rosmarinic acid

\section{IZVLEČEK}

\section{VPLIV RAZLIČNIH DEJAVNIKOV NA INDUKCIJO LASASTIH KORENIN PRI JANEŽNEM OŽEPU (Agastache foeniculum (Pursh) Kuntze)}

Bakterija Agrobacterium rhizogenes je znana kot naravno orodje genskega inženiringa pri mnogih rastlinskih vrstah. $\mathrm{V}$ tej raziskavi so prvič preučevali indukcijo lasastih korenin pri janežnem ožepu (Agastache foeniculum (Pursh.) Kuntze) z uporabo bakterije $A$. rhizogenes, vsebnost rožmarinske kisline in vpliv različnih gojišč ter inokulacijskih metod na rast lasastih korenin. Kulturo lasastih korenin janežnega ožepa so vzgojili iz izsečkov enomesečnih listov inokuliranih $\mathrm{z}$ bakterijo A. rhizogenes sev A4 $\mathrm{z}$ uporabo dveh inokulacijskih metod - potapljanje in vbrizgavanje, $v$ razmerah na svetlem in v temi. Pri metodi potapljanja izsečkov v bakterijsko suspenzijo so preučevali tudi vpliv časa (3,5 in $7 \mathrm{~min})$ na indukcijo korenin. $\mathrm{V}$ drugem delu raziskave so preučevali vpliv različnih osnovnih gojišč (MS, 1/2 MS in B5) na kulturo lasastih korenin. Vsebnost rožmarinske kisline $\mathrm{v}$ transformiranih lasastih koreninah in netransformiranih koreninah so analizirali s HPLC metodo. Značilna razlika v indukciji lasastih korenin v odvisnosti od metod inokulacije ni bila ugotovljena. Opazovanja so pokazala, da je bil odstotek indukcije lasastih korenin večji, če so izsečke listov potopili $\mathrm{v}$ bakterijsko suspenzijo za pet minut. Indukcija lasastih korenin je bila največja $\mathrm{v}$ razmerah gojitve na svetlobi $\mathrm{v}$ primerjavi z gojenjem $v$ temi. Različna gojišča so se razlikovala $v$ vrsti in količini hranil in so vplivala na rast korenin. Največja rast lasastih korenin $(1.61 \mathrm{~g}$ sveže mase $/ 50 \mathrm{ml})$ je bila dobljena pri polovični koncentraciji osnovnega gojišča $(1 / 2 \mathrm{MS})$. Vsebnost rožmarinske kisline je bila $\mathrm{v}$ transformiranih koreninah značilno večja $(213.42 \mu \mathrm{g} / \mathrm{g}$ suhe mase) kot v netransformiranih $(52.28 \mu \mathrm{g} /$ $\mathrm{g}$ suhe mase).

Ključne besede: Agastache foeniculum, Agrobacterium rhizogenes, gojišče, lasaste korenine, potapljanje, vbrizgavanje, rožmarinska kislina

\footnotetext{
Ph. D. Student of Medicinal Plants, Department of Horticulture, Faculty of Agriculture, Urmia University, Urmia, Iran, norozyelnaz@gmail.com

2 Associate Professor, Horticulture Department, Faculty of Agriculture, Urmia University, Urmia, Iran, b.hosseini@urmia.ac.ir

Professor, Horticulture Department, Faculty of Agriculture, Urmia University, Urmia, Iran, horthasani@yahoo.com
} 


\section{INTRODUCTION}

Anise hyssop (Agastache foeniculum (Pursh) Kuntze) is a perennial herbaceous plant belonging to Labiatae family (Omidbaigi and Mahmoodi, 2010). This plant is native to the United States and Canada (Mallavarapu et al., 2004) and is grown in all regions of the Mediterranean, in Northen and Central Europe (Omidbaigi et al., 2008). Clinical trials have shown that anise hyssop extract is effective in treatment of heart, lung, cough diseases and induction sweating to reduce fevers (Mallavarapu et al., 2004). Essential oils of this plant have anti-bacterial and anti- fungal properties. Anise hyssop has many useful constituents, including monoterpenes and phenyl propanoids. Among these constituents, rosmarinic acid, chlorogenic acid, rutin, apigenin and galangin are important. The antioxidant activity of $A$. foeniculum (98.6 mg.g dry plant) depends on the total content of polyphenols (Matei, 2012).

Many valuable medicinal compounds are found in plant roots; root systems play an important role in determining the temporal and spatial patterns of the activity and synthesis of macromolecules: it has been revealed that in many species of Solanaceae alkaloids are synthesized in plant roots and are transported through vascular tissues to shoots where they accumulate or are converted to other compounds (Hector et al., 1999).

In vitro conditions provide the environmental control and the possibility for addition of precursors needed to increase yields and production of specific secondary metabolites $(\mathrm{Hu}$ and Du, 2006). However, low yields and reproducibility of the cultures are the limiting factor in this context so these limitations have led to the development of new techniques in tissue culture, one of them is hairy root culture ( $\mathrm{Hu}$ and $\mathrm{Du}, 2006)$. Rapid growth, low doubling time, easy maintenance and the ability to synthesize a range of chemical compounds in hairy roots are including the advantages that have made them a permanent source of valuable secondary metabolites production (Hasanloo et al., 2008). Agrobacterium rhizogenes (Riker et al., 1930) Conn. 1942 is a gram - negative soil bacterium, which is known as a natural tool of genetic engineering in many plant species, particularly in dicotyledon plants. A. rhizogenes is the causative agent for hairy root induction in wound site and for some biochemical changes in plant metabolism (Gandi and Giri, 2012).

Gene transfer is a powerful tool for increasing productivity and production of secondary metabolites that are produced in low amounts in normal plants (Sharafi et al., 2013). T-DNA transfer from $A$. rhizogenes $\mathrm{Ri}$ plasmid to plant cells and its integration into the host genome leads to the induction of hairy roots (Srivastava and Srivastava, 2007). Hairy roots have rapid growth, high branching and plagiotropic growth in hormone-free medium and can increase the production of secondary metabolites compared to intact plants (Srivastava and Srivastava, 2007).

Contact between the bacteria and plant cells could be increased by direct injection of bacteria suspension into explants or with immersion plant tissue in bacteria suspension culture (Tomilov et al., 2007). In Arachis hypogaea L. hairy roots induction was obtained by injection method (Geng et al., 2012). The effects of two different inoculation methods (co- cultivation and injection) on induction of hairy roots were evaluated in Trigonella foenum-graecum L.; the results showed that transformation performance was $26 \%$ in injection method and $6 \%$ in co- cultivation method (Akbarian et al., 2011). Amaranthus spinosus L. explants were inoculated using both injection and immersion in bacterial suspensions and highest transformation $(98.57 \%$ ) was achieved using the immersion method (Ajantaa et al., 2012). Light plays a key role in the growth and production of secondary metabolites and hairy roots formation is strongly dependent on the light sensitivity of plants and light conditions applied (Wu, 2007).

For the use of $A$. rhizogenes to transfer genes into plants, various factors such as culture conditions and inoculation time must be optimized (Kabirnetaj et al., 2012). Optimization of nutrient compounds of hairy roots culture medium is necessary to enhance the growth and production of secondary metabolites (Sharafi et al., 2013). The responses to various culture media have been reported in many studies, In Eucommia ulmoides Oliver effect of different culture media (B5, WPM and MS) on the hairy roots growth of were studied 
and the results showed that the maximum amount of hairy roots dry weight $(0.46 \mathrm{~g})$ was found in roots grown on MS media as compared to roots grown on WPM media (Wu, 2007). The effect of four culture media $(1 / 4 \mathrm{SH}, 1 / 2 \mathrm{SH}, \mathrm{SH}, 2 \mathrm{SH})$ on the growth rate of Angelica gigas Nakai hairy roots was studied and $1 / 2 \mathrm{SH}$ was the best medium for the growth of hairy roots (Xu et al., 2009).

Technology of rosmarinic acid (RA) production with cell culture and hairy root culture, have been reported in several plant species (Petersen and Simmonds, 2003). Production of RA in Agastache rugosa (Fisch. \& C.A.Mey.) Kuntze hairy roots increased 14 days after culturing (Lee et al., 2008). Increased production of RA in hairy roots of Plectranthus barbatus Andrews (Coleus forskohlii) and Salvia miltiorrhiza Bunge has been reported (Li et al., 2005; Yan et al., 2006).

In the present study for the first time, hairy roots were successfully induced from leaves of $A$. foeniculum by $A$. rhizogenes A4 and synthesis of RA in transformed and non-transformed roots was investigated. In addition, the effects of culture media and inoculation methods were also evaluated for the growth enhancement of hairy roots.

\section{MATERIALS AND METHODS}

\subsection{Seed culture and preparation of explant}

Agastache foeniculum (Pursh) Kuntze seeds were obtained from the botanical garden of the Urmia University - Iran and were surface sterilized using $70 \%$ ethanol for $1 \mathrm{~min}$ and $2.5 \%(\mathrm{v} / \mathrm{v})$ sodium hypochlorite $(\mathrm{NaClO})$ for $10 \mathrm{~min}$, rinsed three times with distilled sterile water. The seeds were cultured on MS (Murashige and Skoog, 1962) medium containing $7 \mathrm{~g} / \mathrm{l}$ agar. Cultures were maintained at temperature of $25 \pm 2{ }^{\circ \mathrm{C}}$ under a 16-h light/8-h dark photoperiod for seed germination and explants preparation.

\subsection{Establishment of hairy roots and culture conditions}

Agrobacterium rhizogenes (Riker et al., 1930) Conn 1942 agropine A4 strain (bank of microbes at the National Institute of Genetic Engineering and Biotechnology, Tehran-Iran) was used in transformation experiments. Bacteria were grown for $48 \mathrm{~h}\left(\mathrm{OD}_{600}=0.5-0.6\right)$ in liquid LB (LuriaBertani) medium at $28{ }^{\circ} \mathrm{C}$ on a rotary shaker at $180 \mathrm{rpm}$. Leaf segments from 1-month- old seedling of $A$. foeniculum were used as explants for co-cultivation and hairy root induction. The explants were immersed in a suspension of $A$. rhizogenes strain A4. All explants were then placed in MS hormone free media fortified with $3 \%$ sucrose for co-cultivation. After 48 hours cocultivation in the dark at $28{ }^{\circ} \mathrm{C}$, the explants were transferred to the fresh MS medium containing $200 \mathrm{mg} / 1$ cefotaxime. The emerging hairy roots were excised and transferred to $50 \mathrm{ml}$ of $1 / 2 \mathrm{MS}$ (half - strength MS) liquid medium supplemented with $3 \%$ sucrose, in $250 \mathrm{ml}$ conical flasks and grown at $25 \pm 2{ }^{\circ} \mathrm{C}$ on a rotary shaker (Hei-dolph, Germany) in darkness for 2 months.

\subsection{Effect of inoculation method on hairy root induction}

The effects of two inoculation methods (injection and immersion) on hairy root induction by $A$. rhizogenes were evaluated. In the injection method, suspensions of A4 strain was injected in different parts of 1-month- old leaf explants by $0.5 \mathrm{ml}$ insulin syringes (Exel - America). In the immersion method, explants after wounding with scalpel were immersed into a beaker containing the same strain of bacterial suspension. Furthermore, in the immersion method, the effect of inoculation time (3,5 and $7 \mathrm{~min})$ on hairy root induction was examined.

\subsection{Effect of light-dark on hairy root induction}

To determine the effects of light and dark conditions on hairy root induction, the explants were immersed in a suspension of $A$. rhizogenes A4 strain and then incubated separately under dark or light at $28{ }^{\circ} \mathrm{C}$. After 48 hours incubation, the explants were rinsed with sterile water and placed in Petri dishes containing $25 \mathrm{ml}$ of solidified MS medium containing $200 \mathrm{mg} / \mathrm{l}$ cefotaxime. 


\subsection{Influence of various culture media on hairy roots growth}

To optimize suitable culture medium for growth of hairy roots, they were cultured in full strength MS, 1/2 MS and B5 (Gamborg 5) basal media containing vitamins. Thereafter, $1 \mathrm{~g}$ of fresh roots were excised and transferred to $50 \mathrm{ml}$ of the corresponding fresh liquid media in $250 \mathrm{ml}$ conical flasks and grown at $25 \pm 2{ }^{\circ} \mathrm{C}$ on a rotary shaker $(100 \mathrm{rpm})$ in darkness. After 21 days of cultivation, the roots were washed with sterile distilled water and dried with sterile filter paper, then recorded their fresh mass.

\subsection{HPLC analysis of hairy roots}

Transformed and untransformed roots were oven dried $\left(45^{\circ} \mathrm{C}\right)$ for one day. Then, approximately $0.5 \mathrm{~g}$ of dry tissue was used to determine RA content. $5 \mathrm{ml}$ of extraction solution $(2.5 \mathrm{ml}$ methanol and $2.5 \mathrm{ml}$ water) was added to each sample and RA was quantified by an Agilent / 1100 series HPLC system with DAD, model G1315B (USA) and a C18 reverse phase column $(4.6 \times 250 \mathrm{~mm})$ at room temperature. The mobile phase (solution B) was acetonitrile / $5 \%$ acetic acid (7: $3 \mathrm{v} / \mathrm{v})$ with a linear gradient of $50 \%$ solution B to $30 \%$ solutions. RA was detected at $254 \mathrm{~nm}$. Retention time of rosmarinic acid was $5.34 \mathrm{~min}$.

\subsection{Statistical Analysis}

The experiment was carried out in randomized completely design (RCD) with three replicates. The data collected were subjected to analysis of variance test. The means were compared using Duncan's multiple range tests. All statistical analyses were performed using SAS 9.1 software.

\section{RESULTS AND DISCUSSION}

\subsection{Establishment of hairy roots}

In the present study, hairy roots were successfully induced (51.1\%) by infection of 1-month- old leaf explants of $A$. foeniculum with $A$. rhizogenes strain A4. Hairy roots emerged from wounded sites 10 days after infection. Hairy root induction using 1month- old leaves as explants can be related to the high sensitivity of these explants to bacteria that depends on the physiological status of explants tissue (Pawar and Mathesh wari, 2003). Selection of an appropriate strain of bacteria is very important to produce hairy roots (Lee et al., 2010; Avansyans, 2009). The selected transformed roots showed rapid growth rate and tendency for profuse branching and active elongation on MS medium.

\subsection{Effect of inoculation method on hairy root induction}

ANOVA results indicated no statistically significant differences between the two inoculated methods in hairy root induction (Figure 1, 2). Effect of inoculation time (in immersion method) was investigated and it was found that immersion of explants for $3 \mathrm{~min}$ in the bacterial suspension was not sufficient to induce hairy roots. Long term exposure to the bacterial suspension for $7 \mathrm{~min}$ lead to necrosis of explants, so inoculation of explants for 5 minutes was detected as the best time in the immersion method (Figure 3). Contact between bacteria and plant cells can be increased by direct injection of bacterial suspensions into the explants or by immersion (Tomilov et al., 2007). In Arachis hypogaea L., embryonic axes along with cotyledons were injected with a suspension culture of. A. rhizogenes using microliter syringes (Geng et al., 2012). In Leucaena leucocephala (Lam.) de Wit hairy roots were induced by injection of $A$. rhizogenes into the hypocotyls explants (Saifuddin et al., 2013). Various methods of inoculation have huge impact on the rate of entry of foreign genes and their integration into the host genome (Akbarian et al., 2011). Our results are in agreement with other studies, in Arachis hypogaea L. the highest rate of hairy root induction was achieved by immersion for $5 \mathrm{~min}$ and rooting percentage decreased with increasing time of inoculation time (Karthikeyan et al., 2007). 

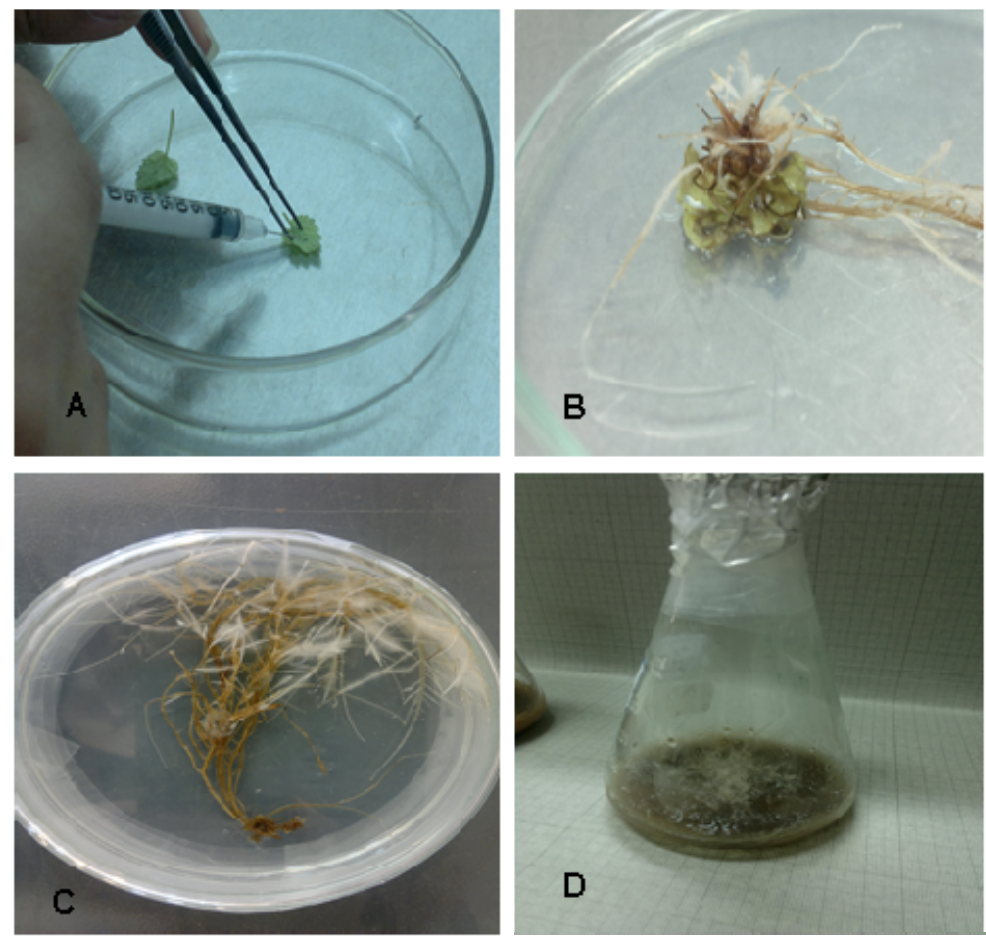

Figure 1: Transformed hairy roots of A. foeniculum by Agrobacterium rhizogenes. (A) Injection of bacteria suspension in the explant (B) Production of transformed roots on 1 - month - old leaf explant (C) Extension of transformed roots in MS solid medium including cefatoxim (D) fast growth of transformed roots in 1/2 MS liquid medium.

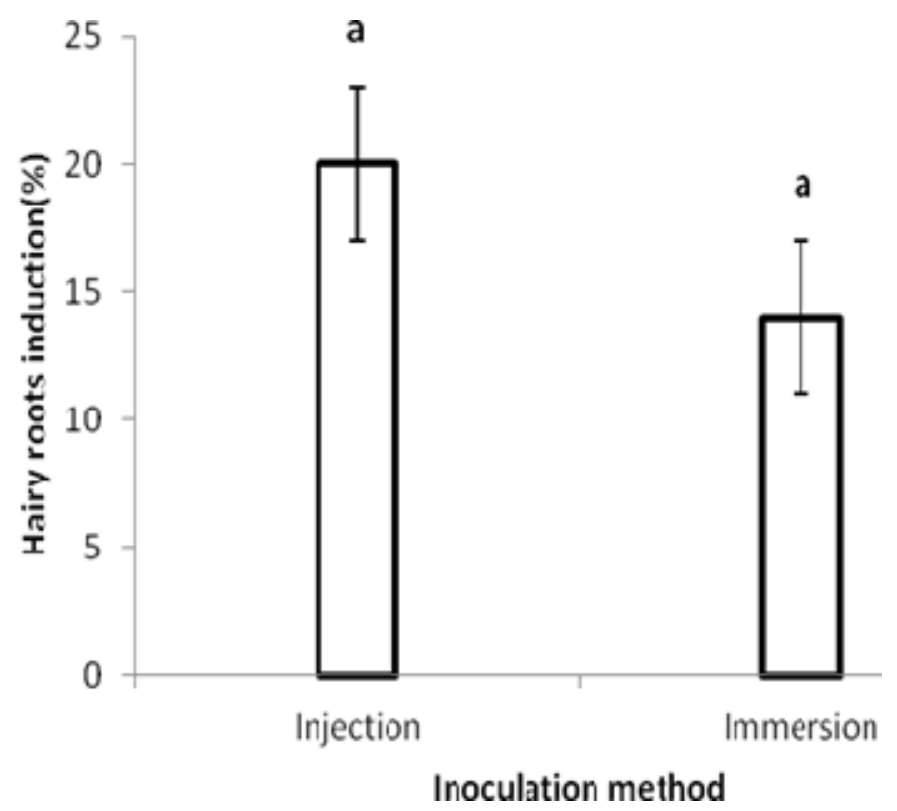

Figure 2: Comparison of immersion and injection methods to induce hairy roots on 1 - month - old leaf explants in A. foeniculum. The data were obtained as mean of three replications. The different letters denote a statistically significant difference at $\mathrm{P} \leq 0.05$, as determined by Duncan's multiple range test. 


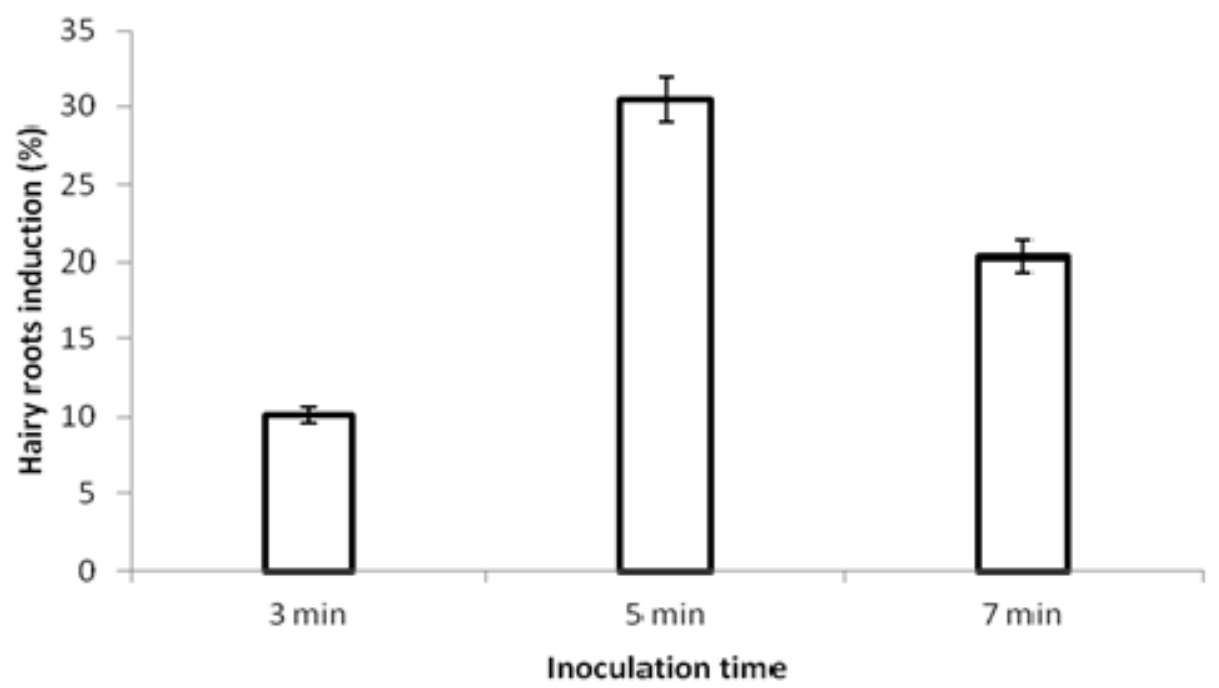

Figure 3: Effect of different co-cultivation times on the hairy root induction in A. foeniculum. The experiment was performed in triplicate and each experiment contained 8 explants.

\subsection{Effect of light- dark condition on hairy root induction}

In the present study, the induction of hairy roots in dark and light incubation was measured (Figure 4). Exposure of transformed explants in light condition improved the hairy root induction and finds it more favorable to hairy root formation than in dark conditions. The highest (39.81\%) and the lowest $(23 \%)$ hairy root induction frequency produced in light and dark conditions, respectively. ATP is required for hairy root elongation through cell division. Therefore, optimal photosynthetic capacity of explants under light environment is primary causes for high transformation (Taiz and Zeiger, 2006).

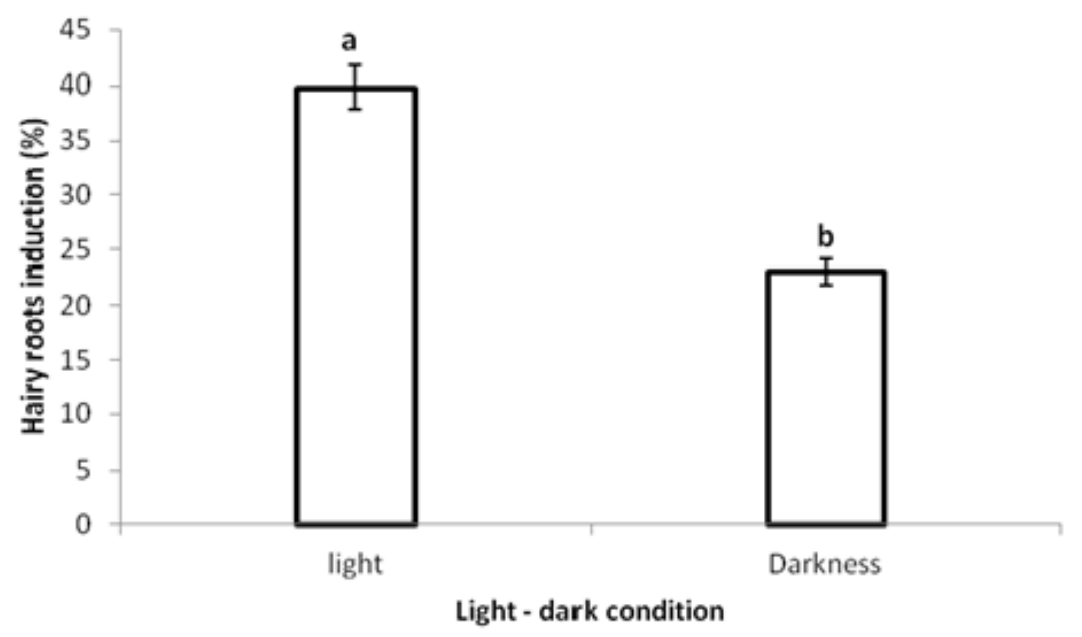

Figure 4: Effect of different light - dark condition on the hairy roots induction in A. foeniculum. The experiment was performed in triplicate and each experiment contained 8 explants. The different letters denote a statistically significant difference at $\mathrm{P} \leq 0.05$, as determined by Duncan's multiple range test. 


\subsection{Effect of basal medium on hairy root growth}

Media composition could have a significant impact on hairy root induction and growth in culture systems (Sivakumar et al., 2005). ANOVA results after 21 days showed significant difference between treatments. It was found that $1 / 2 \mathrm{MS}$ medium produced more biomass $(1.61 \mathrm{~g}$ fr $\mathrm{wt} / 50 \mathrm{ml}$ ) compared to MS and B5 culture media and there was no statistically significant difference between MS and B5 media (Figure 5). The medium type has an important influence on the induction and growth rate of hairy roots. Culture media with high salt such as, MS and LS (Linsmaier and Skoog, 1965) are suitable for the formation of hairy roots in many plants (Giri and Narasu, 2000). Optimization of the hairy root induction and stabilization of the hairy root cultures is important to increase biosynthetic capacity of hairy root cultures (Sharafi et al., 2013). Nutritional factors may influence the number and length of hairy roots (Hilton et al., 1990). It is inferred that the difference in ions of the medium is the primary factor that affect the growth of hairy roots (Wu, 2007). In all three media (MS, 1/2 MS and B5) there is the same amount of calcium and phosphorus, while the nitrogen content was different. MS and B5 medium have the highest amount of nitrogen (approximately 5.22 and $8.26 \mathrm{mM}$ ) but the amount of nitrogen in the $1 / 2 \mathrm{MS}$ medium is less. The growth of hairy roots was limited by high concentration of nitrogen ( $\mathrm{Wu}, 2007)$. Thus, the nitrogen may be a factor that affects the growth of hairy roots. The effect of different culture media (MS, 1/2 MS, B5, 1/2 B5, WP, 1/2 WP) on the hairy roots of Pueraria candollei var. mirifica Airy Shaw et Suvat was studied and the results showed that, 1/2 MS medium produced the highest dry weight of hairy roots $(0.13 \pm 0.03 \mathrm{~g})$ and the lowest dry mass was produced in $1 / 2$ B5 medium (Udomsuk et al., 2009). SH and MS culture media were suitable for the growth of Angelica gigas Nakai hairy roots compared with B5 medium (Xu et al., 2009). Glycyrrhiza glabra L. hairy roots showed the best growth (fresh mass) in NB medium compared with MS, B5 and WP media (Mehrotra et al., 2008).

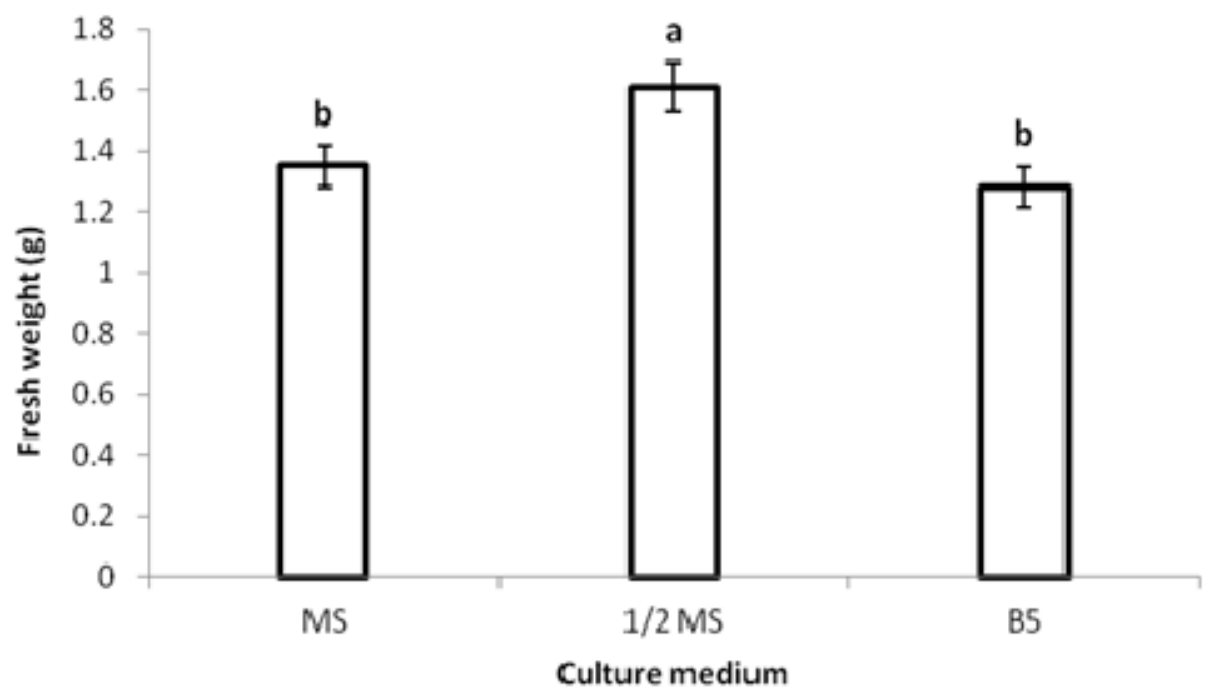

Figure 5: Growth of transformed roots of $A$. foeniculum in different liquid media (MS, 1/2 MS and B5) after 21 days. The different letters denote a statistically significant difference at $\mathrm{P} \leq 0.05$, as determined by Duncan's multiple range test. Vertical lines represent SE.

Hairy roots were cultured in $1 / 2$ MS liquid medium for 2 months and RA content was investigated by harvesting 3 flasks at intervals. RA Content in transformed roots $(213.42 \mu \mathrm{g} / \mathrm{g}$ dry wt) was significantly higher than in non-transformed roots $(52.28 \mu \mathrm{g} / \mathrm{g}$ dry wt) (Figure 6, 7). 


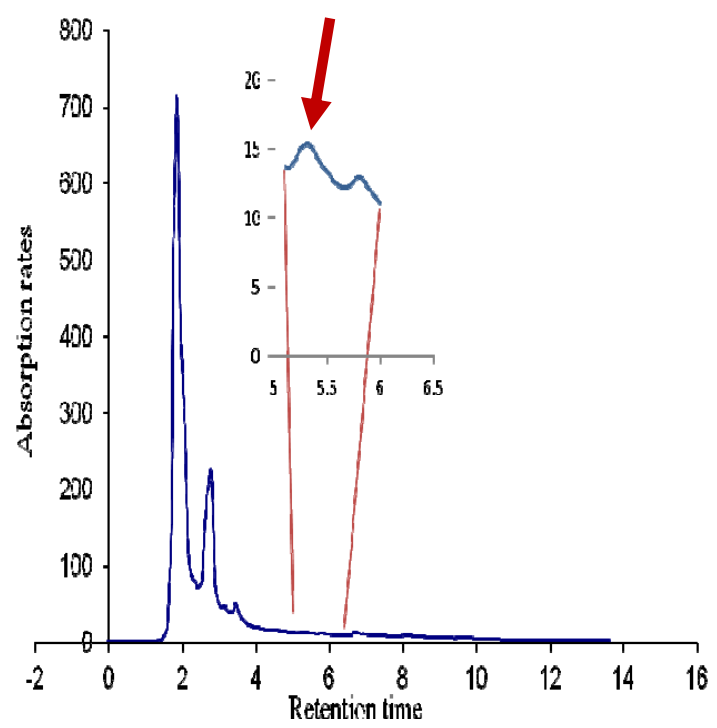

Figure 6: The rosmarinic acid content in hairy roots of $A$. foeniculum retention at 5/34 Min.

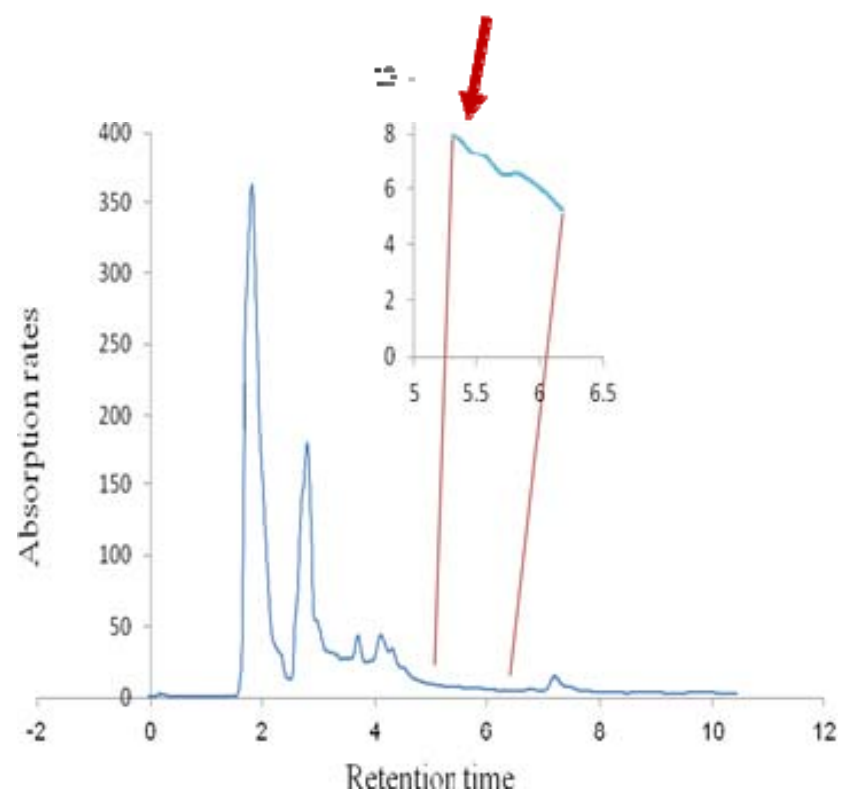

Figure 7: The rosmarinic acid content in non-transformed roots of $A$. foeniculum retention at 5/34 Min.

RA production by hairy root cultures have been reported in many plant species, such as: Coleus forskohlii (Li et al., 2005), Salvia officinalis L. (Grzegorczyk et al., 2006), Agastache rugosa (Fisch. \& C.A.Mey.) Kuntze (Lee at al., 2008), Nepeta cataria L. (Lee at al., 2010). In present study it has been shown that hairy roots can be a valuable source for the production of RA, which is in agreement with the results of other researches. The increase of the amount of RA in hairy roots is probably due to some biochemical changes in plant metabolism by $A$. rhizogenes (Gandi and Giri,
2012). It has been determined that the rol genes are active participants in the production of secondary metabolites, it is known that the rol genes act via transcriptional activation of defense genes (Bulgakov, 2008). Therefore optimization of culture media and other influencing factors on hairy root induction and formation can be used as an efficient method for continuous and high secondary metabolites production in important medicinal plant under in vitro conditions (Sharafi et al., 2013). 


\section{CONCLUSION}

The main outcome of the present study is the development of a reliable and well defined protocol for hairy root induction and increased growth rate in hairy root cultures in A. foeniculum. In the present study, transgenic hairy root cultures of A. foeniculum using A. rhizogenes A4 were established. Suitable explants for hairy root induction proved to be 1 - month - old leaf explants. The effects of injection and immersion methods on the hairy root induction were investigated. Hairy roots were induced with both methods. Hairy root induction was increased in light comparable to dark condition. $1 / 2$ MS medium was the most appropriate medium for culture of hairy roots. Finally, hairy root techniques may be considered as a useful system for large-scale production of valuable secondary metabolites in cultures of $A$. foeniculum.

\section{REFERENCES}

Ajantaa P., Swasti S.S., Arup K.M., Pradeep K.C. 2012. Agrobacterium pRi TL-DNA rolB and TR-DNA opine genes transferred to the spiny amaranth (Amaranthus spinosus L.), a nutraceutical crop. Food Technology and Biotechnology, 51, 1: 26-35.

Akbarian R., Hasanloo T., Khosroshahli M. 2011. Evaluation of Trigonelline production in Trigonella foenum-greacum hairy root cultures of two Iranian masses. Plant Omics, 4, 7: 408-412.

Avansyans R. 2009. Inducion of hairy roots of Papaver somniferom with Agrobacterium rhizogenes and its infection on secondary metabolite. Academic Press, Tehran University, Iran. 250 p.

Bulgakov P. 2008. Functions of rol genes in plant secondary metabolism. Biotechnology Advances, 23, 4: 318-324. $\quad$ DOI: 10.1016/j.biotechadv.2008.03.001

Conn H.J. 1942. Validity of genus Alcaligenes. Journal of Bacteriology, 44: 353-360.

Gandi S., Giri A. 2012. Genetic transformation of Centella asiatica by Agrobacterium rhizogenes. Pharmacognosy Journal, 3: 82-84.

Geng L., Niu L., Gresshoff P.M., Shu Ch., Song F., Huang D., Zhang J. 2012. Efficient production of Agrobacterium rhizogenes - transformed hairy roots and composite plants in peanut (Arachis hypogaea L.). Plant Cell Tissue and Organ Culture, 109: 491-500. DOI: 10.1007/s11240-012-0113-1

Giri A., Narasu M.L. 2000. Transgenic hairy roots: recent trends and applications. Biotechnology Advances, 18: 1-22. DOI: 10.1016/S07349750(99)00016-6

Grzegorczyk I., Krolicka A., Wysokinska H. 2006. Establishment of Salvia officinalis L. hairy root cultures for the production of rosmarinic acid. Zeitschrift fur Naturforschung C, 61: 351-356. DOI: 10.1515/znc-2006-5-609
Hasanloo T., Rezazadeh S.H., Rehnema H. 2008. Hairy roots source for the production of valuable medicinal compounds. Journal of Medicinal Plants, 29: $34-42$.

Hector E., Flores., Jorge M.V., Victor M.L. 1999. 'Radicle' biochemistry: the biology of root-specific metabolism. Trends in Plant Science, 4, 6: 220-226. DOI: 10.1016/S1360-1385(99)01411-9

Hilton M.G., Rhodes M.J. 1990. Growth and hyoscyamine production of 'hairy root' cultures of Datura stramonium in a modified stirred tank reactor. Applied Microbiology and Biotechnology, 33: 132-138. DOI: 10.1007/BF00176513

Hu Z.B., Du M. 2006. Hairy root and its application in plant genetic engineering. Journal of Integrative Plant Biology, 48: 121-127. DOI: 10.1111/j.17447909.2006.00121.x

Kabirnetaj S., Zolala J., Nematzadeh G.A., Shokri E. 2012. Optimization of hairy root culture establishment in chicory plants (Cichorium intybus) through inoculation by Agrobacterium rhizogenes. Iranian Journal of Biotechnology, 4: 61-75.

Karthikeyan A., Palanvel S., Parvathy S., Bhakyaraj R. 2007. Hairy root induction from hypocotyl segments of groundnut (Arachis hypogaea L.). African Journal of Biotechnology, 6: 1817-1820.

Lee S.Y., Lee Ch.Y., Eom S.H., Kim Y.K., Park N., Park S.U. 2010. Rosmarinic acid production from transformed root cultures of Nepeta cataria L. Scientific Research and Essays, 5: 1122-1126.

Lee S.Y., Xu H., Kim Y.K., Park S.U. 2008. Rosmarinic acid production in hairy root cultures of Agastache rugosa Kuntze. World Journal of Microbiology and Biotechnology, 24: 969-972. DOI: 10.1007/s11274007-9560-y

Li W., Koike K., Asada Y., Yoshikawa T., Nikaido T. 2005. Rosmarinic acid production by Coleus

Acta agriculturae Slovenica, 107 - 1, marec 2016 
forskohlii hairy root cultures. Plant Cell, Tissue and Organ Culture, 80: 151-155. DOI: $10.1007 / \mathrm{s} 11240$ 004-9541-x

Linsmaier E.M., Skoog F. 1965. Organic growth factor requirements of tobacco tissue culture. Physiologia Plantarum, 18: 100-127. DOI: 10.1111/j.13993054.1965.tb06874.x

Mallavarapu G.R., Kulkarni R.N., Baskaran K., Ramesh, S. 2004. The essential oil composition of Anise hyssop grown in India. Flavour and Fragrance Journal, 19: 351-353. DOI: $10.1002 /$ ffj. 1316

Matei C.F. 2012. Researches regarding the biology and crop technology of the Agastache foeniculum (Pursh) Kuntze species in the conditions of Transyl vania plane. Academic Press, University of Agricultural Sciences and Veterinary Medicine, Cluj-Napoca.

Mehrotra S., Kukreja A.K., Khanuja S.P.S., Mishra B.N. 2008. Genetic transformation studies and scal up of hairy root culture of Glycyrrhiza glabra in bioreactor. Electronic Journal of Biotechnology, 11: 1-6. DOI: $10.2225 /$ vol11-issue2-fulltext-6

Murashige T., Skoog F. 1962. A revised medium for rapid growth and bioassays with Tobacco tissue cultures. Physiologia Plantarum, 15: 473-497. DOI: 10.1111/j.1399-3054.1962.tb08052.x

Omidbaigi R., Mahmoodi M. 2010. Effect of irrigation regimes on the essential oil content and composition of Agastache foeniculum. Journal of Essential Oil-Bearing Plants, 13: 59-65. DOI: 10.1080/0972060X.2010.10643791

Omidbaigi R., Kabudani M., Khoorang M. 2008. Nitrogen fertilizer affecting herb dry yield, essential oil content and composition of Agastache foeniculum Pursh. Journal of Essential Oil-Bearing Plants, 11: 261-266. DOI: 10.1080/0972060X.2008.10643628

Pawar P.K., Mathesh wari V.L. 2003. Agrobacterium rhizogenes mediated hairy root induction in two medicinally important members of family Solanaceae. Indian Journal of Biotechnology, 3: 414-417.

Petersen M., Simmonds M.S.J. 2003. Rosmarinic acid. Phytochemistry, 62: 121-125. DOI: 10.1016/S00319422(02)00513-7

Riker A.J., Bafield W.M, Wright W.H., Keitt G.W., Sagen H.E. 1930. Studies on infection of hairy root on nursery apple tree. Journal of Agricultural Research, 41: 507-540.

Saifuddin M., Chandy D.M., Osman N., Kalid N. 2013. Induction of fine roots in Leucaena leucocephala using Agrobacterium rhizogenes. Australian Journal of Crop Science, 7: 543-579.

Sharafi A., Hashemi Sohi H., Mousavi A., Azadi P., Dehsara B., Hosseini Khalifani B. 2013. Enhanced morphinan alkaloid production in hairy root cultures of Papaver bracteatum by over-expression of Salutaridinol 7-o-acetyltransferase gene via Agrobacterium rhizogenes mediated transformation. World Journal of Microbiology and Biotechnology, 29, 11: 2125-2131. DOI: 10.1007/s11274-013-1377-2

Sivakumar G., Yu K.W., Paek K.Y. 2005. Production of biomass and ginsenoides from adventitious roots of Panax ginseng in bioreactor cultures. Engineering in Life Sciences, 5: 333-342. DOI: 10.1002/elsc. 200520085

Srivastava S., Srivastava A.K. 2007. Hairy root culture for mass - production of high - value secondary metabolites. Critical Reviews in Biotechnology, 27: 29-43. DOI: 10.1080/07388550601173918

Taiz L., Zeiger E. 2006. Plant physiology. Sunderland, MA:Sinauer Assiociates.

Tomilov A., Tomilov N., Yoder J.L. 2007. Agrobacterium tumefeciens and Agrobacterium rhizogenes transformed roots of the parasitic plant Triphysaria versicolor retain parasitic competence. Planta Medica, 225: 1059-1071. DOI: 10.1007/s00425-006-0415-9

Udomsuk L., Jarukamjorn K., Tanaka H. 2009. Isoflavonoid production in a hairy roots culture of Pueraria candollei. Zeitschrift fur Naturforschung C, 64: 687-69115. DOI: 10.1515/znc-2009-9-1013

Wu X. 2007. Establishment and chemical analysis of hairy root of Eucommia ulmoides. Academic Press, Louisiana State University, China.

Xu H., Park J.H., Kim Y.K., Park N., Lee S.Y., Un S. 2009. Optimization of growth and Pyranocoumarins production in hairy root culture of Angelica gigas Nakai. Journal of Medicinal Plants Research, 3: 978- 981.

Yan Q., Shi M., Ng J., Wu J.Y. 2006. Elicitor-induced rosmarinic acid accumulation and secondary metabolism enzyme activities in Salvia miltiorrhiza hairy roots. Plant Science, 170: 853-858. DOI: 10.1016/j.plantsci.2005.12.004 